\section{Woo-Suk Hwang}

In the West, Woo-Suk Hwang is an enigma. In his home country, he is a scientist with perhaps too much power. In either place, he is a stem cell star.

"Is it Woo-Suk Hwang or Hwang Woo-Suk? Or should we call him Dr. Hwang? Or Professor Hwang?”

At a stem cell conference in San Diego in March, researchers mused aloud before Hwang's arrival how best to address their South Korean colleague. These scientists all knew each other very well, but few had met Hwang before, and even fewer knew much about him. But all of them-and most of the world besides - sat up and took notice when Hwang and his colleagues announced in February 2004 that they had successfully derived stem cells from a cloned human embryo (Science 303, 1669-1674; 2004).

Within South Korea, Hwang needs no introduction. A veterinarian by training, he is one of the country's most prominent scientists, sometimes called its 'national treasure, and lately the model for its push to promote science.

Reflecting Hwang's contrasting renown within his country and outside it, there is also stark disagreement about his nature. Western scientists who have met Hwang praise him as a model of humility and superb skills. But many of his compatriots see things differently.

Hwang's story is the stuff of fables. Born during the Korean War, he grew up fatherless in a poor, isolated town. His mother borrowed money to buy cows, valuable property for a Korean family, and Hwang decided then to become a veterinarian. After a postdoctoral stint in wintry Hokkaido, Japan, he joined the faculty at Seoul National University and specialized in reproductive research in cattle.

Since then, he has steadily built up an impressive roster of accomplishments, including the birth of Korea's first cow using in vitro fertilization in 1993, its first cloned cow in 1999, cloned pigs in 2002 and cows resistant to mad cow disease in 2003. "[Hwang] is proof that you don't just have to be at a Howard Hughes institute or a first-world country to make such splendid discoveries," says Gerald Schatten, a reproductive biology expert at the University of Pittsburgh. "It'd be unfair to say that they're just karate kids."

For 19 years, Hwang has made it a habit to rise at 4:30 a.m. after four hours of sleep, soak in a traditional public bath, and meditate for 40 minutes on the day's plan. On special occasions, he visits a Buddhist temple. He is invariably the first one at the lab and one of the last to leave, often working late into the night over take-out meals and conversations with his medical collaborator Curie Ahn.

Those who have visited Korea say there is a palpable energy in Hwang's team, a veritable army of 125-including the attached labs of Ahn and others - who systematically clone hundreds of cows and pigs. During interviews, Hwang is often accompanied by an entourage of members of his lab. He describes his team as a troop fighting the "war for humanity and curing the disease." Their secret weapon? A mastery of wielding steel chopsticks. "This work can be done much better in Oriental hands," he says. "We can pick up very slippery corn or rice with the steel chopsticks."

Fittingly, the team even has a motto: 'hanul eul gamdong shikyeara' which, loosely translated, means 'moving the heart of the sky.' "That's our team's phrase if we are in difficulties to solve something," says Ahn. "We say let's move the sky and see if it happens-and it happens sometimes."

Moving the sky can be hard work. The researchers work round the clock on what they describe as a "special calendar": their week runs Monday, Tuesday, Wednesday, Thursday, Friday, Friday, Friday, Monday and so on. "Our stem cells cannot realize today is Saturday or today is Sunday, so we have to work every Saturday and Sunday," Hwang explains. Not surprisingly, many of the lab members have over the years married each other.
The atmosphere in Hwang's lab is "very intense, very, very intense," says Jose Cibelli, assistant professor of animal biotechnology at Michigan State University, who collaborated with Hwang on the Science paper. "They're not just after the headlines, they just love what they do."

Cibelli and others say they are impressed with Hwang's simplicity and the way he attends to his students, secretary and visitors. "He's extremely humble, that's for sure," says Cibelli. "That's something that would be nice if we could learn from." Cibelli recalls one instance when he arrived at Seoul's airport, located an hour away from the city. Expecting to see an underling, Cibelli was touched that Hwang himself had come to receive him. "To me, that meant a lot," Cibelli says. "I live in East Lansing, Michigan, where the airport is five minutes away, and I would probably send someone else."

Several in Korea are not nearly so complimentary.

"I should say [Hwang] is a man with many different faces," says Sangyong Song, vice president of the Asian Bioethics Association and a member of UNESCO's Commission on the Ethics of Scientific Knowledge and Technology. "[Hwang] is a genius in building a public image," adds Young-Mo Koo, secretary of the Korean Bioethics Association. "Idon't think he is a humbleman, he's just pretending to be humble," Koo says. "He sells himself very well."

"This work can be done
much better in Oriental
hands. We can pick up
very slippery corn or rice
with the steel chopsticks."

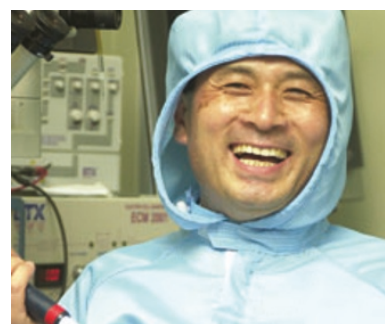

Hwang fell into disfavor with bioethicists amid questions over whether a graduate student in his lab had donated eggs used for his experiments. Such research would usually be carefully screened for ethical considerations before being given the go-ahead, but at the time, Korea did not have legislation or bioethics guidelines on cloning. "Such things as conflict of interest wouldn't necessarily have occurred to [the researchers]," says Australian stem cell expert Alan Trounson. “There's a conventional wisdom we have but [that] assumption in a hierarchical society may not necessarily happen.”

Hwang says the questions are merely the result of the student's poor English. "If I force some graduate students to [donate eggs], it might arise a very big social problem in Korea," he says. "If the accident will come out, it may fail me forever, eternally."

The bioethicists maintain that the questions are serious enough to warrant an investigation, but haven't seen any response. "I would say we are sick and tired of their behavior," says Koo. "We do not want to do any conjecture. We don't know, that's why we called an investigation. That's the bottom line."

Critics say the government is using Hwang's fame to promote science and is reluctant to investigate anything that might tarnish his reputation. Hwang is often seen on Korean television and is approached for autographs by everyone from children to famous rock stars. Since last year, a much larger proportion of federal funds has also been prematurely funneled into stem cell research, some say, marginalizing more modest basic research.

Hwang is trying to differentiate the stem cells and testing them in rat and dog models of spinal cord injury. Even if he accomplishes nothing else for the rest of his career, he is guaranteed a place in the history books. "We started from the bottom and worked our way up to where we are today," he says. "My name is already listed in primary and secondary school [textbooks]."

Apoorva Mandavilli, San Diego 